\title{
IF We HaVe SEEN FURTHER, IT IS BY STANDING ON THE SHOULDERS OF GIANTS
}

Dear Editor,

In April 1960, Dr. Álvaro Gómez-Leal, a hematologist trained at the Instituto Nacional de Nutrición Salvador Zubirán (INCMNSZ), presented during the first meeting of the Agrupación Mexicana para el Estudio de la Hematología, A.C., data on a transplant of allogeneic stem cells in a patient with acute leukemia done in Monterrey, Mexico (Fig. 1A): the patient received high-dose chemotherapy followed by stem cells from the bone marrow of his brother, improving and obtaining remission for months but relapsing and subsequently died. This was the first report of a hematopoietic stem cell transplantation (HSCT) conducted in Mexico, only 4 years after the pioneer work by $\mathrm{E}$. Donnall Thomas in Cooperstown, New York, USA ${ }^{1}$. Years later, in 1980, Ricardo Sosa and his coworkers

\section{REFERENCES}

1. Thomas ED, Lochte HL, Lu WC, Ferrebee JW. Intravenous infusion of bone marrow in patients receiving radiation and chemotherapy. N Engl J Med. 1957;257:491-6. at the INCMNSZ conducted and published formally a $\mathrm{HSCT}^{2}$. Since then, more than $7500 \mathrm{HSCT}$ s have been performed in México in over 10 HSCT centers, headed by physicians either trained at the INCMNSZ of by their trainees (Fig. 1B).

May this be an homage to the institution which now celebrates its $75^{\text {th }}$ anniversary and to the physicians involved in starting the HSCT activity in Mexico, who taught us that the obstacles are there to be surpassed. In an era in which the practice of HSCT was restricted to few centers in high-income countries, we were taught that they could be done in low- and middle-income countries. Despite these outstanding achievements, in México, we are performing only $5-10 \%$ of all the HSCT that should ideally be done. We still have a long way to go along the road started by true giants.

\footnotetext{
2. Sosa-Sánchez R, Córdova-Caballero MS, Labardini-Méndez J, ChávezPeón F. Trasplante de médula ósea en anemia aplástica. Reporte del primer trasplante en México. Rev Invest Clin Mex. 1980;32:49-55.
}

Guillermo J. Ruiz-Argüelles ${ }^{1 *}$, David Gómez-Almaguer ${ }^{2}$, Guillermo J. Ruiz-Delgado ${ }^{1}$, ANDRÉS GóMEZ-DE-LEÓN², AND IVÁN MURRIETA-ÁLVAREZ ${ }^{1}$

${ }^{1}$ Centro de Hematología y Medicina Interna de Puebla, Clínica Ruiz, Puebla, Puebl.; ${ }^{2}$ Hospital Universitario de Nuevo León, Monterrey, NL., Mexico

*Corresponding author:

Guillermo J. Ruiz-Argüelles

E-mail: gruiz1@clinicaruiz.com
Received for publication: 09-07-2021

Approved for publication: 10-07-2021

DOI: $10.24875 /$ RIC. 21000363

0034-8376 / (c) 2021 Revista de Investigación Clínica. Published by Permanyer. This is an open access article under the CC BY-NC-ND license (http://creativecommons.org/licenses/by-nc-nd/4.0/). 
Figure 1. (A) Abstract of the paper presented by Dr. Alvaro Gomez-Leal in April 18, 1960, during the first congress of the Agrupación Mexicana para el Estudio de la Hematologia held in Mexico City. (B) Number of hematopoietic stem cell transplants conducted in some centers in México. IMSS: Instituto Mexicano del Seguro Social; UMAE: Unidad Médica de Alta Especialidad; UANL: Universidad Autónoma de Nuevo León; CMN: Centro Médico Nacional; ISSSTE: Instituto de Seguridad y Servicios Sociales para Trabajadores del Estado; INP: Instituto Nacional de Pediatría; INCMNSZ: Instituto Nacional de Ciencias Médicas y Nutrición Salvador Zubirán; ABC: American British Cowdray.

TRLNSPLANTES DE MEDULA OSE: EN EL SER HUMINO.

Dr. Llvaro Gomez Leal.

Se revisan las bases inmunologicas de la práctica de los in-

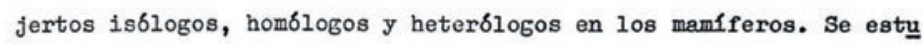
dian los principales reportes on relacion a los transplantes de m6 dula ssea on roodores, cánidosy primates, que permiten suponer que sea posible efectuarlos on el hombre. Se establecen 2 grupos de pa decimientos hematologicos en que los transplantes humanos serian aplicables: uno, formado por la anemia aplástica, las anemias hemo liticas congónitas y la agamaglobulinemia, en el que se utiliza-rf́an transplantes de médula 6sea homóloga, y otro, constituía por problemas malignos, en que se podria intentar una erradicación del padecimiento con agentes antineoplásicos y después salvar la vida del paciento con un injerto homólogo, aunque tambión puede efectuarse antologo, si so toma el producto durante un periodo de remision $y$ se conserva viable hasta el momento necesario.

So revisan y discuton los diferentes obstáculos que tienen los transplantes humanos, sobre todo en relacion con la inhibicion de la intolerancia inmunolbgica para los tejidos homologos. Se ana liza la dosis de rayos $\mathrm{X}$, la cantidad de collulas que se deben administrar y la técnica de obtención y preservación de las mismas.

Finalmente, se discuten los resultados obtenidos por otros autores y se presentan brevemente los alcanzados por el autor.

A

- Escuela de Medicina de.Ia Universidad de Nuevo Ioón. Hemat 1 logo del I.M.S.S.

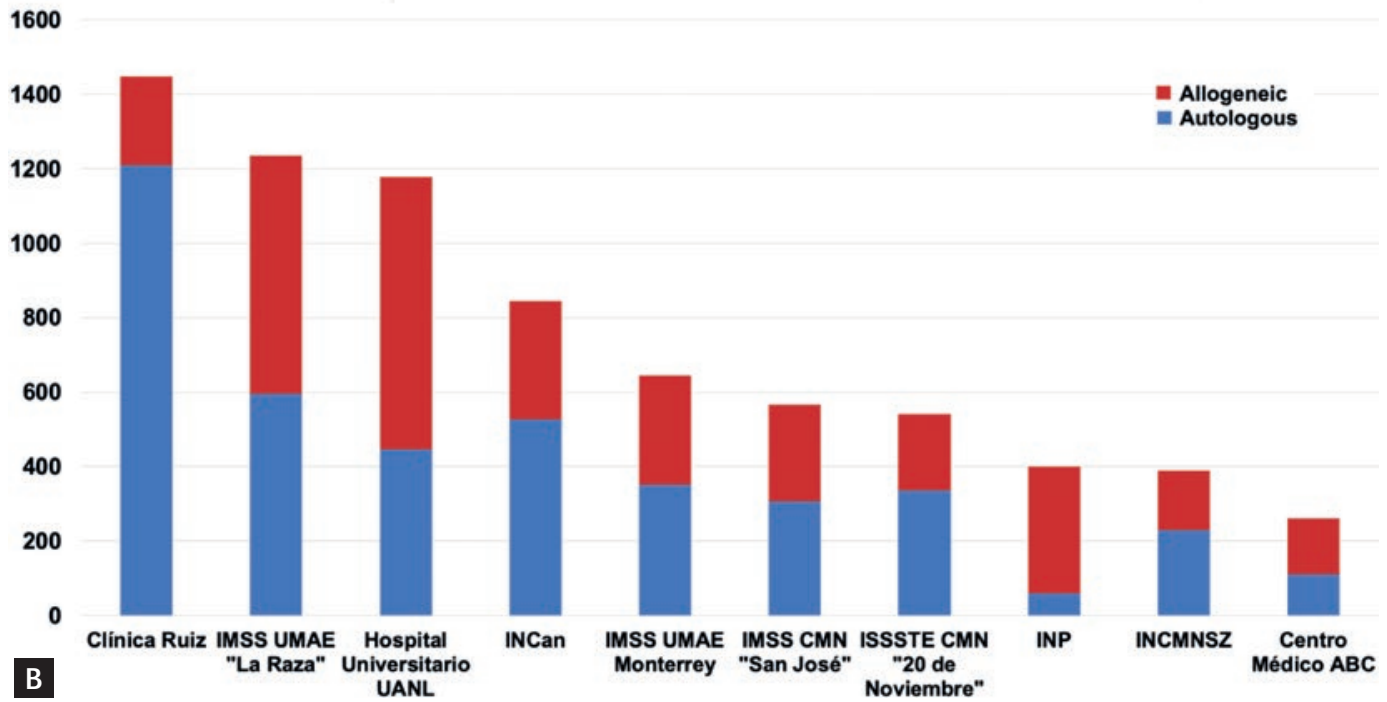

